\title{
End of Life: A Family Narrative
}

\author{
Helen K. Black, ${ }^{1}$ Miriam S. Moss, ${ }^{1}$ Robert L. Rubinstein, ${ }^{2}$ and Sidney Z. Moss ${ }^{1}$ \\ ${ }^{1}$ Behavioral Research Institute, Arcadia University, 450 South Easton Road, Glenside, PA 19038, USA \\ ${ }^{2}$ Department of Sociology and Anthropology and Center for Aging Studies, University of Maryland, Baltimore County, \\ 1000 Hilltop Circle, Baltimore, MD 21250, USA
}

Correspondence should be addressed to Helen K. Black, blackh@arcadia.edu

Received 19 October 2010; Accepted 16 March 2011

Academic Editor: Laraine Winter

Copyright () 2011 Helen K. Black et al. This is an open access article distributed under the Creative Commons Attribution License, which permits unrestricted use, distribution, and reproduction in any medium, provided the original work is properly cited.

This paper is based on ethnographic research that examines family reaction to an elderly husband and father's end of life. From a group of 30 families in our study (family defined as a widow aged 70 and over and two adult biological children between the ages of 40 and 60), we offer an extreme case example of family bereavement. We report our findings through the open-ended responses of a widow and two children who were interviewed ten months after the death of the husband and father. Three general themes emerged: (1) how the family imputes meaning to the end of life, (2) changes in the roles of family members, and (3) the family's ways of coping with the death, particularly through their belief system. A key finding is that the meaning family members find in their loved one's death is tied to the context of his death (how and where he died), their perception of his quality of life as a whole, and their philosophical, religious, and spiritual beliefs about life, death, and the afterlife that are already in place.

\section{Introduction}

The trajectory of family life-incipience, development, and decline-includes the end of life. An important aspect of end of life studies is the context in which death occurs $[1,2]$. In the case of an elderly husband and father, his family members are usually participants in the end of life process and interpreters of the meaning of his death [3]. Much has been written about this stage by scholars in various disciplines [4-7], yet there is little research on the responses of family members as a family when asked how death occurred for their loved one and its meaning to them.

Our paper springs from a study entitled "The Meaning of the Death of the First Elderly Parent: A Family Perspective," which investigated family (including the wife/widow and two biological adult children) members' reactions to the husband and father's end of life. This paper explores how one family communicated their experiences in the forum of the research interview. We focused on how family members made meaning of the husband and father's end of life through their roles in the family, and their unique ways of coping with anticipated and actual loss, especially through their belief systems.
Our paper contributes to the literature on end of life and family bereavement by placing the death of an elderly man in the cultural context of his family's narratives about his dying and death. First, we examine the salient terms used in our paper, such as the nature of the family, family roles before and after the husband's and father's death, and finding meaning in his life and death. We describe the methods we used in our research, present findings through a unique case study, and offer a discussion.

\section{Finding Meaning through Belief Systems}

In this paper, we view religion, spirituality, and the syncretized belief systems of individuals and families as a culturally and socially driven way of forming values about the end of life. Personal belief systems are tools used to interpret the world and what we see within that world [8]. A belief system both provides and seeks meaning in the wake of negative events.

In regard to dying and death, a crucial aspect of a belief system, whether formal religion, personal spirituality, or a folk religious belief, is in its functions of creation and continuity. A belief system creates or discovers an answer to 
the why of suffering and to the meaning of life and death [9]. A belief system may also attempt to create or maintain continuity with the deceased in a way that makes sense to the bereaved and their notion of the loved one's and the family's singularity [10].

\section{Methods}

3.1. Theoretical Framework. We situated our research in a theoretical approach to end of life experiences that is social constructionist in nature [11]. This approach is based on three frameworks. The first is phenomenology and the sociology of knowledge, which focuses on how people understand everyday life and see meaning making and interpretation as key human actions. The individual is the creator of a personally meaningful world of lived experience and is best able to explain his world [12]. The second is drawn from the psychology of religion, which is strongly cultural and shows belief systems as cultural lens through which individuals interpret and restructure negative experiences [9]. The third is rooted in contemporary bereavement theory which explores family interactions at the end of life, the meaning of loss, the tie with the deceased, and expressions of mourning within the family context [13].

3.2. Data Collection and Analysis. This paper emerges from data collected from NIA-funded research "The Meaning of the Death of the First Elderly Parent: A Family Perspective." In the original study we interviewed 30 families, consisting of a widow aged 70 and over and one or two adult children, aged 40 to 60 , from six months to one year after the father and husband's death. We recruited respondents from the notice of death that appeared in local newspapers. We collected data for this study through formal ethnographic interviews and informal conversation. Data were processed through audiotaping and transcription for analysis or detailed in analyzable field notes. The case that follows was culled from both processes.

The subjects of this paper had private interviews in their homes approximately ten months after their loved one's death. Each interview lasted approximately two hours in two sessions. An IRB-approved consent form was obtained from each family member at the beginning of the first interview.

The main tool of the study was the semistructured interview schedule, which included open ended questions that spanned two sessions. The first interview session focused on the reaction of the interviewee to the husband or father's decline and eventual death. This interview also explored the respondent's opinion of his end of life care. The first interview also examined respondents' reactions to rituals performed after death and beliefs about religion, spirituality, and an afterlife. The second interview asked for opinions related to other family members' reactions to the husband and father's dying and death and an assessment of relationships among family members in general and specifically in relation to the loved one's end of life.

The general approach to data analysis in the project was as follows: after transcribing interviews, we analyzed them using standard methods of qualitative research. This method includes data review, which asks the broad questions, "What is in the data?" and "How is this data relevant to the topic under study?" The next step is a large level sorting of each transcript, which codes for broad themes and topics intraindividually $[14,15]$. We also did fine-grained analyses, which include coding for subthemes and patterns within respondents' entire transcript. Our method enabled us to better understand the respondents' interpretations of questions we asked them. The data we used in this paper emerged from gross level sorting and fine-grained analysis. We note that as new data were transcribed and ideas and themes emerged, we back checked them selectively or universally with data from respondents who had already completed an interview.

3.3. Rationale for Use of the Case Study. Our use of one family (three persons, the widowed mother, and two adult children) to illustrate the family responses to the father/husband's end of life justifies the case study method as a necessary and sufficient means of showing a phenomenon of lived experience. In this case, it is the family's perception of the meaning of the husband and father's end of life [16].

We use the case that follows because it shows a concentrated family experience. That is, all members of this family-father, mother, and three adult children-lived together in the family home for over 50 years. Their enduring intimacy with each other created a unique context for a family response to the end of life and produced insight into the goal of our research: the exploration of how a family comes together around the decline of the elderly father and husband and whether the family makes a collective meaning of his death. The case study disclosed the family's united experiences of grief, as well as, each member's unique perception of the death due to having a particular relationship with the deceased [16].

We used three themes to organize major aspects of the family's narrative: (1) how the family imputes meaning to the end of life; (2) the past and present role of each family member and, (3) the family's ways of coping with the death, particularly through their belief systems. We see the themes as interrelated. That is, finding meaning in a loved one's death is an aspect of coping with loss. Meaning can also be found through: (1) recalling his good works and death as an end to his suffering, (2) a belief system that assures his existence in an afterlife, and (3) continuing or expanding each family member's present role in the family. Three themes emerged from our data, based on family members' answers to interview questions, spontaneous remarks throughout the interview, and our interpretation of their nonanswers, silences, pauses, emotion, and body language.

3.4. The Marino Family (a Pseudonym That Reflects the Italian-American Background of This Family). We present the Marino family. Joseph Marino, Sr. died in February of 2009, ten months before the start of our interviews. He was 87 and a survivor of colon cancer, open heart surgery, and a minor stroke. He endured several other health problems for 
two years prior to death. His widow, Frances, is aged 84 . The couple had been married 64 years at the time of his death. Their first son, Joseph, Jr., is a lawyer. At age 62, he has never married, is semiretired, and works from a private office in the family home. The middle child, Cub, is 60 years old and also single. He held odd jobs throughout life and is currently unemployed. Pauline, the 52-year-old daughter and youngest child of the family, is "between jobs." Although she left home to marry when she was in college, she returned after the two-year marriage ended in divorce. Joseph Jr. lived away from home for six years on an extended work project. He returned home when the work was completed. Cub never left the family home.

According to family members' accounts, Joseph Sr. sat alone in the kitchen on a Saturday in February, 2009. All family members were home and in different rooms of the large suburban house. Frances "heard a thump," ran to the kitchen, and found Joseph Sr. on the floor, next to his chair. All family members responded to Frances' scream. In retrospect they believe that he "just slipped off the chair" and died.

3.5. Themes. We explore how the Marino family reacted to Joseph Sr's end of life within three inter-related themes: (1) how the family imputes meaning to the end of life; (2) the past and present role of each family member; (3) the family's ways of coping with their experience, particularly through their belief system.

Family members organize thoughts and feelings surrounding the loved one's end of life in the interview narrative. We suggest that individual and family belief systems provide a way to discover meaning in the life and death of the deceased, as well as, an important means of coping with loss [17].

3.5.1. Theme One: How the Family Imputes Meaning to the End of Life. Pauline was the first person interviewed in the Marino family. As the youngest child, Pauline believes that throughout her life she was considered "special" and "protected" by her father and grandfather, who lived with the family when she was a child. When asked, Pauline described the last year of her father's life.

He had a stroke the day before New Year's Eve, 2007. Within the next year he really went down. But they never diagnosed anything. He dropped a lot of weight. Then he developed urinary infections. He got inflammation of the blood and they could not find what caused that. I'm big on holistic things like cranberries for infections. But nobody listened to me. My mother was in control. My oldest brother was next in line.

Pauline notes important family characteristics. There is a long-standing family hierarchy, and because she is the youngest child and a daughter, she occupies the bottom rung and feels disrespected and unheard. She also attributed qualities to her father that the family agreed upon: he was an uncomplaining, loving, and "handsome superman."
He must have suffered terrible, but he never let us know. "Cause he looked like Omar Shariff until the day he closed his eyes." He was going to doctors all the time to get blood work done. He finally said, "No more doctors. No more blood work." His body was tired.

When asked to tell the story of her father's death, Pauline said:

It was Saturday morning. He kept saying to my mother, "Fran, when you coming in?" He could not stand to be in a room without her. And I heard her go in and scream over and over. We all ran in. No stress on his face. I think it was a peaceful death. And his father passed away the same way. It was like in the Godfather movie.

Although "knowing" he was "fading at least a year before his death," Pauline clarified that no one in the family "expected" him to die. She explained: "My father was the cement of the family." Family members agreed that Joseph Sr. gave the family its purpose as a family. The metaphor of cement was apt and recurring in Pauline's narrative. Joseph Sr. was a stone mason, construction worker, and carpenter. He had built their home, its "insides," and its several additions "with his own hands."

Because of his central role in the family, Pauline feared that the "entire family" might "come apart" when Joseph Sr. died.

Before he died, I was frightened. I did not know how I was going to react. God forbid the day it would happen, I thought we would all be hysterical. We were upset and sad, but he died in his own chair and his own home. And we all rallied together because he kept us together because he was at peace.

For Pauline, the meaning of her father's death emerges from the precariousness of her position in the family, despite the family unity she felt when he died. She now feels "at the mercy" of her brother, Joseph, Jr. and his "controlling" personality. She believes that her childhood fear of him stunted her ability to trust people.

My brother used to be boss of all the attorneys at $\mathrm{N}$ Corporation. So he thinks that now my father is gone... It started from when I was a child. My parents both worked. My grandfather used to protect me, then he passed away but I could tell my father when Joseph (Jr.) bullied me. When it was just me with Joseph, he would put me in the chair in the corner when I was bad, or scare me about monsters and I would scream and cry. I said, "You wonder why I am the way I am today." See, even though the last two years (of father's life) he was not able to do anything anymore, it was just that physicalness of him being here, protecting me. 
Pauline suggested that the meaning of Joseph Sr.s life and death centers in their home; the house itself symbolizes his attributes, such as physical strength and protection. But the meaning of the home has changed for Pauline. She commented, "My father had a strong physical presence. It's gone out of the house. It's cold in here."

Joseph Jr. agreed with Pauline that the family "came together" at the end of his father's life. He attributed his strength and the family's solidarity to prayer.

We all ran into the kitchen that day in February. But I knew his time had come, and I felt thankful because it looked like he went to sleep. And I knelt down and kissed him, and held his hand and told him how much I loved him. The Lord granted my wish-I was able to accept it because I knew his time had come.

Similarly to the way Pauline described her father as "tired," Joseph Jr's phrase, "his time had come" suggests that his perceived readiness erased visions of Joseph Sr. fighting death. All family members, however, believe that Joseph Sr. was afraid of dying. Joseph Jr. also feared his father's death, but for reasons different from Pauline's.

His death was something I feared for the last five years. He was failing physically. I prayed for the Lord to give me strength to bear God's will. A few days before he died, my father said, "I'm not going to any more doctors or any hospitals." When we went to bed, he would always say, "See you tomorrow." He did not say it Friday night. But we all kissed him, as was our tradition. He had a feeling his time was coming. It was a bitter-sweet experience. Bitter because we lost our father and the center of our family. But sweet in that it was a fitting end for a good man. In fact, Saint Joseph, as you might know, is the patron saint of a happy death.

One meaning that Joseph Jr. found in his father's life and death was to emulate him, despite believing he would never reach his father's stature.

I wish I had my father's physical capabilities, his personal courage and fortitude. He was fearless. If somebody threatened us, he was like a raging lion. And just to be good the way he is. But I just do not have that innocent goodness he had.

Interviewer: What do you mean by innocent goodness?

Joseph, Jr.: It's that he did not really hate people... with the exception of one cousin who disrespected my mother. But he would not talk ill of people. And he would take great joy in a nice tomato in the yard, or after he finished doing some concrete work. But as I've gotten older I'm doing better at it. He was physically very strong. His little finger was the size of my thumb.
To his family, Joseph Sr. was literally "larger than life." Although Joseph Jr. believes that his father loved his children equally, his father was especially proud of the authoritative positions Joseph Jr. held in the corporate world. "It was important to my father that we stay together and that I take care of the family. I take this seriously." Joseph Jr. described himself as the family member that others turn to. When asked who supplied support when he was grieving, he replied evenly:

I told you I prayed to have strength to accept this when it came. We bonded together in an hour of pain. They all look to me now. Not that I could take my father's place, but if push comes to shove, I'm the one they come to. I see the loss of my father had its toll on my mother. My brother and sister have enough to contend with their own lives. So grieving is a luxury I cannot afford.

Joseph Jr. said that the family is "different now. What's missing in the family is this sense of a rock. Now that he's gone, we're not the same, we're less." This statement describes the family's sense of depletion.

Frances, Joseph Sr.'s widow, believes "it's a lie" when someone says they are prepared for a loved one's death. She always told her husband, "You can die one day after me; not before." Because "it was difficult to see my superman failing" and she knew he was afraid of death, the couple never discussed this subject.

He aged magnificently. He never looked ill, he just got even better looking. The nurses that came here would say that to me. He was a superman; he looked like a superman. A few days before death, he became just a shell of a person.

Frances said that she found meaning in her husband's death by participating in our research. "We're not educated for death and we should be." She regrets that they did not talk about death but she knew he was "unable." She laments that she did not "assure him that I loved him just as much as he loved me," and hopes he was unaware of how impatient she felt at times.

In the last year he'd go in the shower but he could not do it by himself. I would go in with him and bathe him. I would help him on with his clothes; I would cream his face. And he would just look at me and say, "I cannot believe you have to do this." I'd say, "Joe, if the shoe was on the other foot, you'd do this and more, too."

He was astounded by how much I did for him without him asking.

She found another meaning in her husband's death.

He loved me so much; he adored me. A highlight of his life was when I decided to go out with him, when we were engaged, when we got married, and when we had children. I realized after he died that I loved him as much as he loved me. 
Unlike other widows in our study, Frances noted that another meaning she found in her husband's death is that she "must be there more" for her children. She also feels, similarly to other widows in our study, that she is paying a great price for being so beloved by her husband. "Without him, my life has very little meaning."

\subsubsection{Theme Two: The Past and Present Role of Each Family} Member. The most important role in the family continues to be held by Joseph, Sr. Perhaps because he remained the "cement" of the family even at the end of life, his widow's and children's roles seemed less definitive after his death. The family wondered whether their roles still existed or whether they could carry out those roles.

During our first interview, Joseph Jr. described his father with adages that mythologized him, such as "good as bread", "like Saint Joseph," and "the Saint Joseph of the neighborhood." Both Pauline and Joseph Jr. described their father as "a saint." Frances disagreed and said she had a more "realistic" view of her husband. She remembered that the children always "looked up to Joe, whereas I had the firm hand." As disciplinarian, she thinks she was considered the "bad guy" by her children. The adult child she most worries about is Pauline.

She was always a challenge. She never really did anything with her life, with her education. My husband spoiled her. She was supposed to go on to become a lawyer, like her brother. Then she got married, then she got divorced. So she never really did anything. And she never did housework.

Frances described both of her sons as "good looking but not as handsome as my husband." "Joe was hardest on Joseph Jr. He wanted him to be somebody. And he is." She described her youngest son, Cub, as "not the dexterous type and he does not want to be. He's the lazy type (laughs) but very affectionate." Frances did not seem disappointed in Cub; she simply asserted that neither son reached the pinnacle of manhood in looks or strength that her husband had.

Because Frances' identity consisted mainly of being a wife and mother, she misses her role as the most important person in Joe's life. Frances does not want to be dependent on others and in fact thinks of herself as "more independent now," but "less secure and less safe. I always thought I was independent, but my independence was through Joe." She believes that Joseph Sr. made her feel independent by driving her "everywhere" and doing whatever she asked of him. Her husband bolstered her self-esteem by his devotion to her.

I'm really alone, really. You could say, Well, how can you say that? You have three children. Yes, I have three children, but I hide a lot from them, they're not fully aware of what I'm going through. And I would not want them to be.

Of all family members, Joseph Jr. seemed the most content in his life and family role after his father's death, perhaps because he believes he exceeded his father's expectations.
Joseph said his role as "head of the family" was given to him symbolically by his mother a few years before his father died. One day she got up from her seat at the foot of the table and said to him, "You should sit here now." He felt honored.

Joseph Jr. described his father's relationship with Pauline as "doting." He thinks his father was "frustrated" with Cub because of his weak work ethic. And although Joseph Jr. sees himself as taking on his father's role due to his "ranking, Pauline definitely does not see it that way, and Cub sees me as a usurper, taking my father's place, but with no right to do so." Joseph understands that "Pauline thinks I'm trying to be the boss. While my father was here she knew I could not be in control." Pauline often threatens to leave the family home when their mother dies. Joseph Jr. thinks "she'd feel lost without my brother and myself."

Pauline admitted she is afraid of the future; life without her father represents a lack of security. Both Frances and Joseph Jr. recognize Pauline's vulnerability, but they view it differently. Frances remembers that Joseph Jr. helped Pauline out financially "countless times" and will continue to do so. She knows that Joseph is "glad" to help his siblings "with money." Yet, Frances recognizes that the help Pauline needs is more emotional than financial and worries that Joseph Jr. does not share this understanding. Joseph reiterated:

Now I'm the head of the family. My mother thinks that way too. So for that reason I sort of publicly defer to my mother as being the head of the family, but it's really me.

Roles in the family and the meaning of events, such as Joseph Sr.'s death, are enhanced by symbolic gestures. Along with Frances giving up her place at the table to Joseph, the family decided to forgo decorations the first Christmas after Joseph Sr.'s death. The holiday was a reflection of their powerful emotional state. They suspended their Christmas rituals (lights throughout the house, a large crèche, a Christmas Day open house). Frances described the family dinner. "When Pauline broke down, everybody broke down."

3.5.3. Theme Three: Coping with the End of Life, Particularly Through Belief Systems. Belief systems help individuals and families endure the loved one's dying and the grief that follows his death. Frances is uncertain about the content of her beliefs, but knows that she lacks the ardor of her children's faith.

It would help if I could say that I believe in an afterlife. But deep down, I do not. And my mind tells me no. The children come back at me, "How can you say you're a Catholic? The Resurrection, you know, Mother." And I said, "Well, I'd be lying. Do you want me to lie?"

Frances handles her grief by focusing on the children. She knows she must accomplish some practical tasks before she becomes ill or incapacitated. She must help her children realize how much she cares about them and not to worry about her.

Pauline managed her father's decline and death through her spirituality, which blended Catholic dogma, new age 
spirituality, the spiritual significance of coincidence and clairvoyance, and possession of a "sixth sense." The coincidences she encountered before our interview convinced her that her family should participate in our study.

Pauline reported that her grandfather wanted her mother to attend Beaver College (now Arcadia University). Receiving a letter from Arcadia University requesting participation in research on end of life was a "sign." On the first meeting, Pauline said that the interviewer (H. K. B.) "could pass for the double of their good neighbor." Pauline believed her father choreographed these coincidences.

She attributed her ability to handle her father's death to "prayer," which helped her through the funeral that she remembers "in a haze." Accepting his death was due to "Divine intervention." "The peacefulness of him, I think helped us cope."

Joseph also looked to his belief system to help him endure his father's decline and passing. When Joseph was asked how important his Catholic beliefs are in everyday life, he replied:

It's the center of my life. It's the focus of my life.... And I think that my Catholicism was a major part in helping me to come to terms and being prepared for my father's death. And in assuming my role in life as head of the family, now that my father is not here. So, yes, it's the core of my life.

The Marino family felt a sense of pride in the dignity they displayed when Joseph Sr. died. They believed they had "done right" by adhering to his wishes for "no more doctors or hospital." Pauline spoke for the entire family. "We had no regrets."

\section{Discussion}

It may be expected that an elderly husband's end of life will disrupt his widow's sense of self, her life roles, and notions about the future [18]. The expectation for such a disruption in the lives of adult children is lessened by the breadth of their social worlds. Their grief is often diffused by the competing needs of spouses, children, and grandchildren [19]. We note that the significant persons in the Marinos' lives were each other. Among participants in our study, the Marinos were the only adult children who remained in the family home throughout their lives. The singularity of their living arrangements and relationships with each other made them an extreme case example [16].

The encapsulated world of the Marinos engendered consistency not only in each of their narratives about Joseph Sr.'s end of life, but also in the emotional investment they made in him. Widow and children agreed that he was the "cement of the family," and all worried that the family might "come apart" without him. Family members united around their belief that Joseph Sr. wanted them to "stay together" in the family home.

In regard to their unified grief, the Marinos may have differed in degree but not in kind from other widows and adult children in our study. Most of our respondents united around the "we" of the family in constructing a narrative about the meaning of the husband and father's life, dying, and death. Their recollection of experiences and roles from the recent and distant past shaped and continues to shape relationships with other family members.

We used three themes to organize the major aspects of the family's narrative of Joseph Sr's end of life: (1) how the family imputes meaning to the end of life, (2) the past and present role of each family member, and (3) The family's ways of coping with their grief, particularly through their belief systems.

Frances, Joseph Jr., and Pauline found meaning in viewing Joseph Sr.'s qualities as remarkable. They described him with superlatives and viewed his peaceful death as befitting his "good" life. Similarly, most family members in our study highlighted whatever was notable about their loved one's life and death, what distinguished him from others, and his irreplaceable role in their families and their lives [1]. Unlike other families, however, it was not Frances who sanctified her husband's life [20], but the children who viewed their father as "saintly" and as possessing "an innocent goodness."

In regard to family roles, Joseph seemed to relish his new role as "head of the family." Frances said she must take on the task of "getting the children ready for when I'm not here any more." Pauline believed that her role in the family became precarious when her father died. Although their roles are peculiar to their unique family, the idea of "taking on" or "trying out" a new role in the family after the death of the husband and father was not unusual in our sample of families. Many "new" roles of adult children centered on concern for their mother and how and where she will live out her life [21]. Unlike Frances, most widows did not feel it was their job to comfort bereaved children. Rather, widows in our sample felt disappointed that their children could not understand the loss they were experiencing [22].

Pauline's and Joseph's belief systems helped them endure their father's end of life. Joseph Jr. finds great comfort in his Catholic faith, and Pauline thinks that her "sixth sense" attunes her to manifestations of her father's presence in her life. Frances does not find solace in traditional Catholic tenets, such as a belief in an afterlife, but continues to pray to Jesus and favorite saints daily. Similar to Pauline and Frances Marino, most family members we interviewed followed an idiosyncratic spirituality. Sources for belief systems were a blending of beliefs and practices of various religions, family and cultural myths, stories, and superstitions, and popular versions of traditional religions.

It is likely that the Marinos, because of the intensity of the family tie, remain more dependent on each other for their roles and for the meaning they create from Joseph Sr.'s life and death than more typical families in our study. Yet, the Marinos typify most bereaved families, who, like links in a chain in which a major link is gone, go about their lives, sometimes tightening the remaining links.

\section{Acknowledgments}

The authors are extremely grateful to the family of Mr. Marino for sharing their stories of his death with us. Data 
described here were gathered in a research project entitled, The Meaning of the Death of the First Elderly Parent: A Family Perspective (Supported by NIA Grant number 5R01AG31806-2, Robert L. Rubinstein PI). We are grateful to NIA for its support of our research.

\section{References}

[1] V. Cigoli and E. Scabini, Family Identity: Ties, Symbols, and Transitions, Lawrence Erlbaum Associates, New York, NY, USA, 2006.

[2] M. Kagawa-Singer and L. J. Blackhall, "Negotiating crosscultural issues at the end of life," Journal of the American Medical Association, vol. 286, no. 23, pp. 2993-3001, 2001.

[3] R. L. Winzeler, Anthropology and the Study of Religion, Altamira Press, New York, NY, USA, 2000.

[4] L. Bregman, Introduction to Religion, Death, and Dying: Perspectives on Dying and Death, Praeger, Santa Barbara, Calif, USA, 2010.

[5] B. Hayslip and C. A. Peveto, Cultural Changes in Attitude toward Death, Dying, and Bereavement, Springer, , New York, NY, USA, 2005.

[6] R. Kastenbaum, Death, Society and Human Experience, Allyn and Bacon, Boston, Mass, USA, 2007.

[7] A. Kleinman, Culture and Depression, Oxford University Press, 1985.

[8] S. Eisenhandler, Keeping the Faith in Late Life, Springer, New York, NY, USA, 2003.

[9] H. Black, Soul Pain: The Meaning of Suffering in Late Life, Baywood, Amityville, NY, USA, 2006.

[10] G. Smith, A Short History of Secularism, I. B. Tauris, New York, NY, USA, 2008.

[11] P. Berger and T. Luckmann, The Social Construction of Reality: A Treatise in the Sociology of Knowledge, Anchor Books, Garden City, NY, USA, 1966.

[12] R. L. Rubinstein, "Narratives of elder parental death: a structural and cultural analysis," Medical Anthropology Quarterly, vol. 9, no. 2, pp. 257-276, 1995.

[13] G. A. Bonanno, C. B. Wortman, and R. M. Nesse, "Prospective patterns of resilience and maladjustment during widowhood," Psychology and Aging, vol. 19, no. 2, pp. 260-271, 2004.

[14] E. Mischler, Research Interviewing: Context and Narrative, Harvard University Press, Cambridge, Mass, USA, 1986.

[15] S. David, Interpreting Qualitative Data: Methods for Analyzing Talk, Text and Interaction, Sage, Thousand Oaks, Calif, USA, 2001.

[16] B. Flyvbjerg, "Five misunderstandings about case-study research," Qualitative Inquiry, vol. 12, no. 2, pp. 219-245, 2006.

[17] D. Carr, R. M. Nesse, and C. B. Wortman, Spousal Bereavement in Late Life, Springer, New York, NY, USA, 2006.

[18] N. Abeles, T. L. Victor, and L. Delano-Wood, "The impact of an older adult's death on the family," Professional Psychology: Research and Practice, vol. 35, no. 3, pp. 234-239, 2004.

[19] D. Umberson, Death of a Parent, Cambridge University Press, Cambridge, Mass, USA, 2003.

[20] H. Z. Lopata, Widowhood in an American City, MW Books, 1973.

[21] M. Moss and S. Moss, "The death of a parent," in Midlife loss: Coping strategies, R. Kalish, Ed., Sage, Newbury Park, Calif, USA, 1989.
[22] K. A. DeMichele, "Memories of suffering: exploring the life story narratives of twice-widowed elderly women," Journal of Aging Studies, vol. 23, no. 2, pp. 103-113, 2009. 


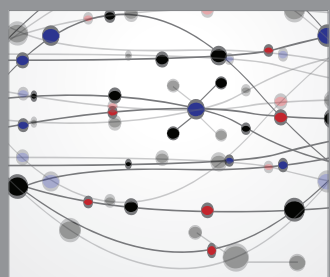

The Scientific World Journal
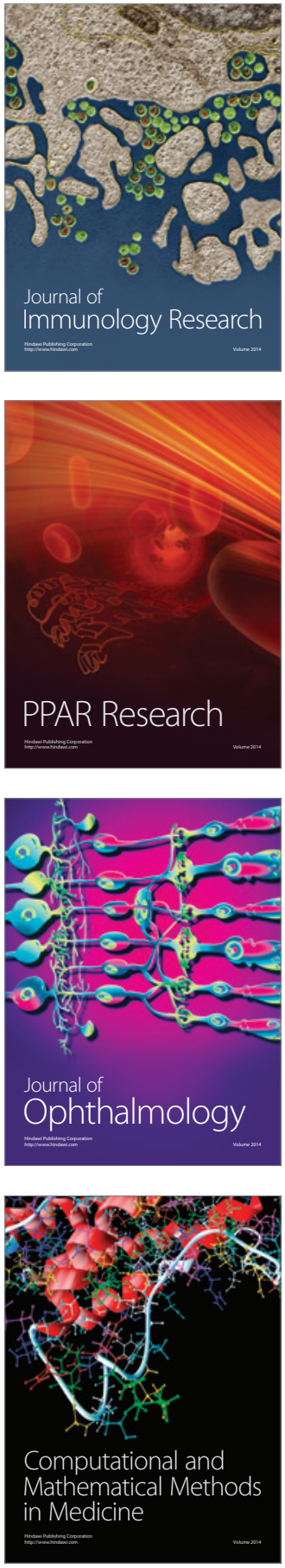

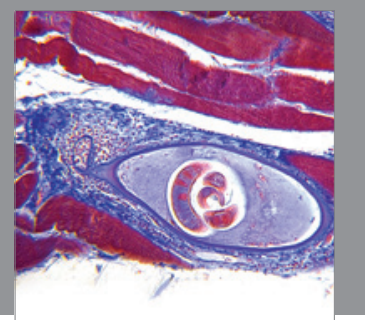

Gastroenterology

Research and Practice
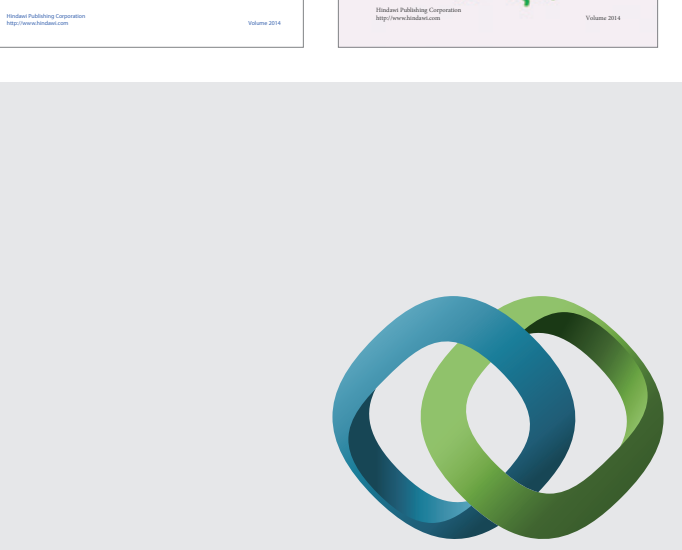

\section{Hindawi}

Submit your manuscripts at

http://www.hindawi.com
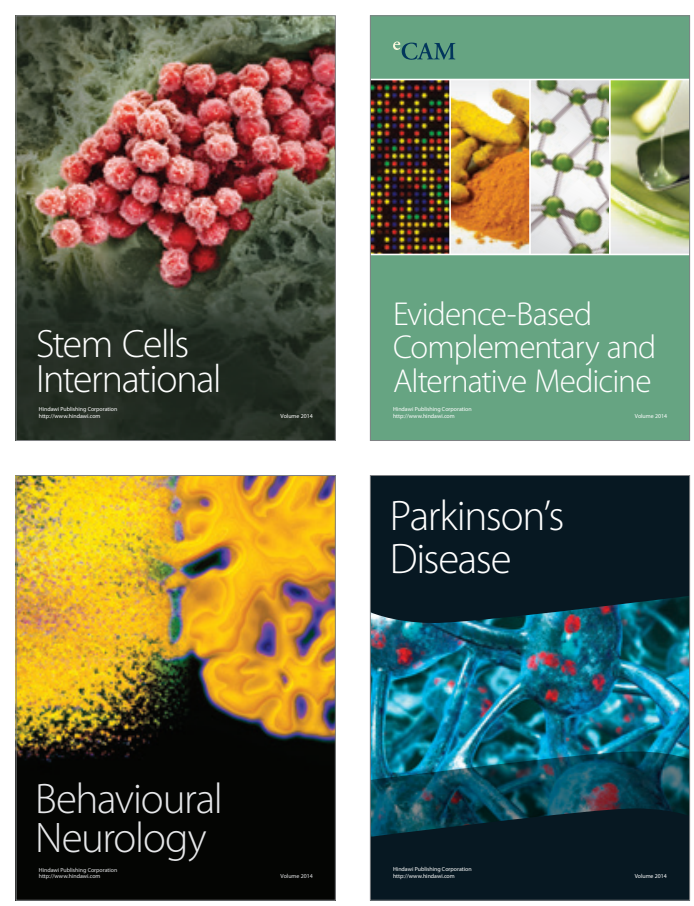

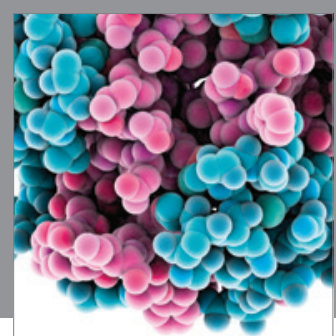

Journal of
Diabetes Research

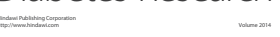

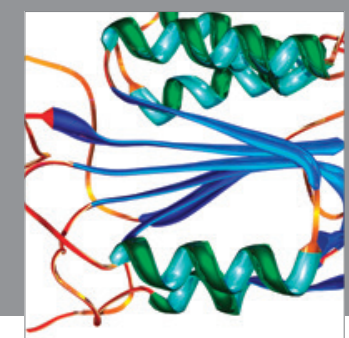

Disease Markers
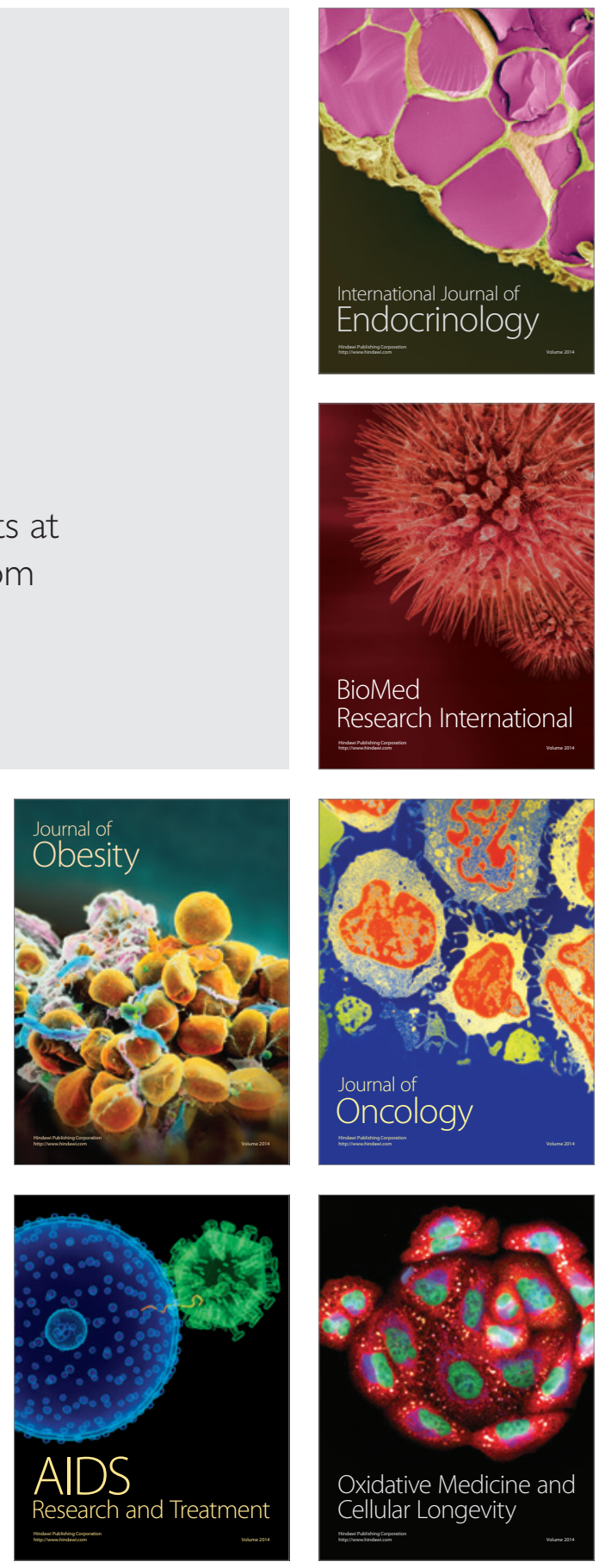